\title{
$\mathrm{BIM}$ 기술과 화재시뮬레이션의 연동방안에 관한 연구
}

\section{A Study on the Interworking Method of BIM Technology and Fire Simulation}

\author{
이병흔* · 진승현** . 김동은*** . 권영진**** \\ Lee, Byeong-Heun*, Jin, Seung-Hyun**, Kim, Dong-Eun ${ }^{* * *}$, and Kwon, Young-Jin ${ }^{* * * *}$
}

\begin{abstract}
In Korea, the use of BIM in designing is consistently increasing, and in line with current situation, it is necessary to find a method that can interconnect the existing fire simulation and BIM. In this study, we suggested an interworking method of Add-on Program that is possible link with BIM, and conducted a case study with existing programs. Further, it was tested by comparing the temperature at any point. Comparing the result of maximum temperature, a difference of approximately $0.3{ }^{\circ} \mathrm{C}, 2.4{ }^{\circ} \mathrm{C}$, and $17{ }^{\circ} \mathrm{C}$ was observed in case of T-1, T-2, and T-3. The reason of difference was that a human user cannot create the coordinates like a computer when developing the fire model. In the future, there will be consideration to conduct more case studies.
\end{abstract}

Key words : BIM Technology, FDS, Add-on Program, PBD

\section{요 지}

국내의 경우 $\mathrm{BIM}$ 을 이용한 설계는 지속적으로 증가할 것으로 전망되며, 설계방법이 $\mathrm{BIM}$ 으로 변경되는 현 실태에 맞춰 기존의 화재 시뮬레이션과 BIM의 연동이 가능한 방안을 모색할 필요가 있다. 본 연구에서는 BIM과 연동이 가능한 Add-on Program의 연동방법과 기존 프로그램과의 Case Study를 진행하였으며 온도 비교를 위해 임의의 지점의 온도를 비교하는 방식으로 테스트를 진행하였다. 최대 온도를 비교한 결과 $\mathrm{T}-1$ 의 경우 약 $0.3{ }^{\circ} \mathrm{C}, \mathrm{T}-2$ 의 경우 약 $2.4{ }^{\circ} \mathrm{C}, \mathrm{T}-3$ 의 경우 약 $17{ }^{\circ} \mathrm{C}$ 의 차이를 보였다. 이는 사용자가 화재모델을 구축할 때 컴퓨터와 동일하게 좌표를 작성할 수 없기 때문에 발생하는 차이로 사료되며 향후 다양한 Case Study를 진행할 필요가 있다.

핵심용어 : BIM기술, FDS, Add-on Program, PBD

\section{1. 서 론}

건축물의 화재안전에 있어서는 실제 상황에서 같은 조건으 로 화재실험을 수행하는 것이 신뢰성이 높지만, 다수의 건축 구조물에 맞춰 실물모형을 제작하는 것에는 많은 비용을 요구하기 때문에 현실적으로 어려움이 따르게 된다. 이에 대한 대책으로서, 시뮬레이션에 의한 화재모델링이 주로 사용
되고 있다. 주로, NIST사의 FDS가 이용되는데 특히 대형화, 초고층화 및 복합화 기능을 갖는 건축물의 방화대책을 수립함 에 있어 효율성을 높이기 위해 지속적으로 활용되고 있다.

또한, 피난안전성평가라는 개념이 도입되고 법제화되면 서 시뮬레이션을 이용한 화재안전평가는 적극적으로 사용 되고 있다. 소방방재청 고시 제 2013-10호 “소방시설 등의 성능위주설계 방법 및 기준”에 규정하고 있는 내용에 따르면

*정회원, 호서대학교 소방방재학과 박사과정(E-mail: 1118930z@naver.com)

Member, Doctor's Course, Department of Fire \& Disaster Prevention of Hoseo University

**정회원, 호서대학교 소방방재학과 박사과정

Member, Doctor's Course, Department of Fire \& Disaster Prevention of Hoseo University

****정회원, 대전보건대학교 재난건설안전과 교수

Member, Professor, Department of Disaster Construction Safety of Daejeon Health Institute of Technology

*****교신저자, 정회원, 호서대학교 소방방재학과 교수(Tel: +82-41-540-5497, Fax: +82-41-540-5738, E-mail: jungangman@naver.com)

Corresponding Author, Member, Professor, Department of Fire \& Disaster Prevention of Hoseo University 
소방관계기준에 따라 제도화된 설계를 성능위주설계로 대 체할 때는 적절한 공학적 분석을 통해 화재안전의 수용가능 수준이 예측 가능한 사용 조건 내에 달성할 수 있는지를 증명하는 것에 있다.

따라서, 건축물의 설계 시점부터 화재시뮬레이션의 활용 은 불필요한 재정적 손실을 막을 수 있음과 동시에 인명보호 및 재산 손실을 방지하게 해주었다.

이와 별개로 최근 초대형 및 비선형 건축물의 등장은 건축물 설계기술에 변화를 가져왔으며 이러한 과정에서 등장한 Building Information Modeling (BIM)의 개념은 평면 적인 설계에서 벗어나 $3 \mathrm{D}$ 모델링을 통해 건축물의 생애주기 동안 관련정보를 통합하고 이를 설계에서부터 유지관리 까지 관리하는 체계를 의미한다(Choi, 2009; Lee, 2010).

국내에서도 2016년 조달청에서 발주하는 300억 이상의 사업은 의무적으로 $\mathrm{BIM}$ 기술을 적용하고 있으며, $\mathrm{LH}$ 에서는 2020 년부터 설계공모의 $100 \%$ 를 BIM으로 발주하는 것을 추진 중이다. 또한, 국토교통부에서는 공공건설분야 BIM 로드맙 및 활성화 전략을 계획하는 등 $\mathrm{BIM}$ 을 이용한 설계는 지속적으로 증가할 것으로 전망된다(Cho et al., 2016; Shin et al., 2016). 따라서, 설계방법이 BIM으로 변경되는 현 실태에 맞춰 기존의 화재 시뮬레이션과 $\mathrm{BIM}$ 의 연동이 가능 한 방안을 모색할 필요가 있다.

본 연구에서는 BIM과 연동이 가능한 Add-on Program을 개발하기 위해 국내에서 사용빈도가 높은 Autodesk 사의 Revit과 FDS의 연동 방안을 고안하였고 Case Study를 통해 해당 프로그램의 신뢰성에 대해 검토했다.

\section{2. $\mathrm{BIM}$ 기술의 적용범위 환경조사 및 체계화}

화재위험성을 평가하기 위해서는 주로 시뮬레이션을 이 용하여 해당 건축물의 위험도를 평가하게 되는데 이때 시뮬 레이션의 신뢰도는 모델의 정확도에 의해 결정되며 출화부
터 소화까지 과정에서 일어나는 화재성장, 연기이동, 피난, 독성 등을 계산하기 위해서는 공학적 기법을 이용하여 연소, 유체역학, 열역학 등의 이론, 가연물과 점화원에 대한 데이터 베이스 또는 실제 화재실험이나 화재사례에 대한 자료 등을 활용하게 된다.

이러한 화재안전평가는 대상 건물을 모델화 시키는 것부 터 시작이다. 따라서, 건축물의 외곽을 모델화하기 위해서는 사용자가 직접 전산로직으로 작성해서 입력하게 되며 Table 1 과 같은 순서로 로직을 작성하게 된다. 하지만 이러한 화재 의 모델화에 있어 건축자재의 데이터 및 가연물 데이터의 부족, 화재시뮬레이션 구동의 변수, 수정이 필요한 재작업의 번거로움 등의 문제점을 가지게 된다. 이러한 문제점을 해결 하기 위해 Pyrosim이라는 전처리 프로그램이 존재한다.

하지만, $3 \mathrm{D}$ 형태로 가시화 시키는 것에 그치며 건축자재 및 가연물 데이터 등에 대한 정보제공 및 사용자가 건축물을 모델화해야 하는 것에는 변함이 없다.

이러한 문제점을 해결하기 위해서는 Fig. 1과 같은 BIM과 $\mathrm{FDS}$ 간의 데이터 연동이 이뤄지고 동시에 건축자재 및 가연

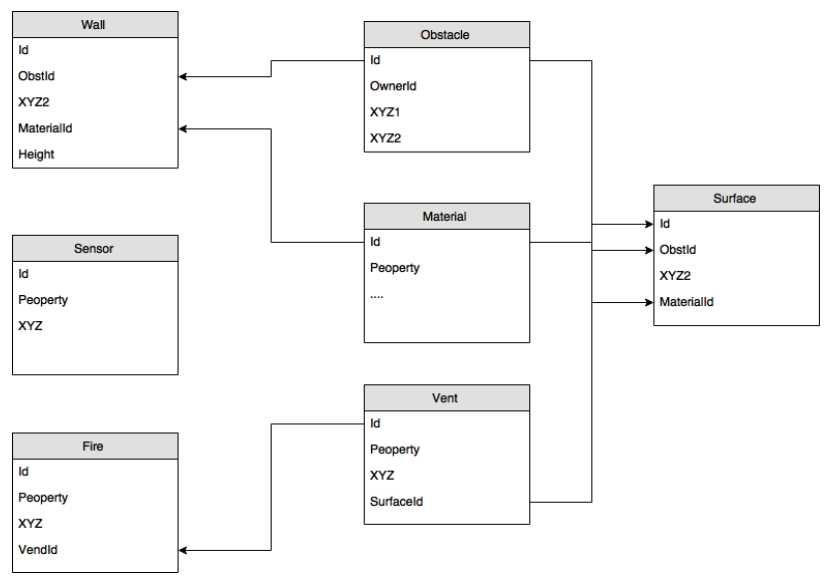

Fig. 1. Database Structure

Table 1. Fire Simulation Input Order

\begin{tabular}{c|l|l|l}
\hline No. & \multicolumn{1}{|c|}{ Purpose } & \multicolumn{1}{c}{ Result } & \multicolumn{1}{c}{ Input Command } \\
\hline 1 & Size of Calculation Space & Size Modeling Space & MESH \\
\hline 2 & Accuracy of Calculation & Cell Size & MESH \\
\hline 3 & $\begin{array}{l}\text { Ventilation Controlled Fire \& Fuel } \\
\text { Controlled Fire }\end{array}$ & Size of Open Space & VENT \\
\hline 4 & Fire Situation & Fire Condition and Combustion Range & OBST, SURF \\
\hline 5 & Calculation Time & Simulation Calculation Time & TIME \\
\hline 6 & Chemical Figures of Combustion Target & Fire Mechanical Results Calculation & REAC, MATL \\
\hline 7 & Elicitation of the Result Value & $\begin{array}{l}\text { Types for Calculating the Results of Fire } \\
\text { Mechanics }\end{array}$ & ISOF, SLCF, BNDF \\
\hline 8 & Visual Transparency Processing & Visual Direction for Transparency & OBST, HOLE \\
\hline 9 & Three-dimensional Structure Formation & Simplification Form of Structure & OBST, HOLE \\
\hline 10 & Pyrolysis Inside a Substance & Granularity of Pyrolysis Material & SURF \\
\hline
\end{tabular}


물 데이터를 동시에 연산할 수 있는 방안을 찾을 필요가 있다(Lee, 2018).

따라서, 데이터베이스 구축을 위하여 두 개의 별개 데이터 인 건축물 라이브러리와 FDS 라이브러리를 하나로 통합하 는 과정을 수행한다. 예를 들어 Revit에서 스프링클러로 지정된 개체를 $\mathrm{FDS}$ 에서도 스프링클러로 인식하기 위해서 는 두 개체 사이의 연동이 이뤄져야 한다. 즉, 두 라이브러리 에서 공통된 부분을 하나로 찾는 과정이 필요하며, 프로그램 의 연동과정에서 이를 불러올 수 있도록 데이터베이스화 시키는 작업이 필요하다.

따라서, 데이터베이스를 체계화하며 하나로 합치는 과정 에서 필수 데이터 필드와 부차적인 데이터 필드를 구분하여 데이터베이스 스키마(Database Schema)를 작성하였다(Lee, 2012).

이 때 $\mathrm{BIM}$ 정보에는 존재하지 않지만 화재시뮬레이션 결과 도출에 필요한 비열, 밀도 발열속도 열전도도 흡수계 수 등의 데이터가 추가되어야 하기 때문에 MATL DB를 구축하기 위해 기존의 실험 결과를 활용하였다(Kim, 2015; Lee et al., 2019, 2020) 데이터는 관리 및 확장성을 위해 엑셀 기반으로 작성하였다.

\section{BIM기반 화재시뮬레이션 연동을 위한 시스템 기획}

Fig. 2는 Revit과 FDS의 연동이 가능한 Add-on Program (이하, FDSBIM으로 작성)의 관계도이다. Revit을 통해 입력 되는 데이터를 기반으로 화재모델링에 필요한 정보를 취합 한 뒤 FDSBIM을 통해 입력된 데이터가 연산되어 나타나는 일련의 과정을 나타내고 있다(Lee, 2015).

$\mathrm{FDSBIM}$ 의 구동에 필요한 데이터는 Revit Application Programming Interface (API), MATL DB, Mesh Data, Analysis Options 등으로 분류하였다.

Revit API은 화재시뮬레이션을 구동시키는데 필요한 물 리 정보 중 $\mathrm{BIM}$ 에서 추출할 수 있는 건축물의 데이터를

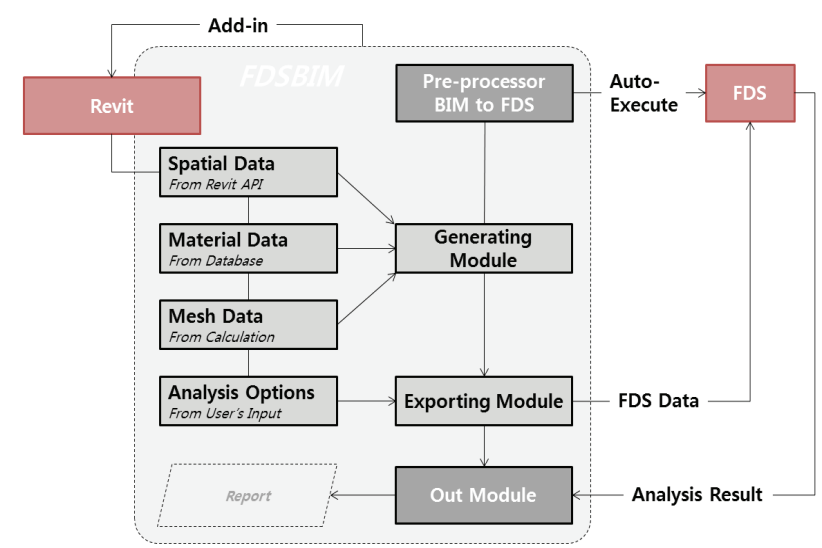

Fig. 2. System Structure of FDSBIM



Fig. 3. Information Extracted from BIM

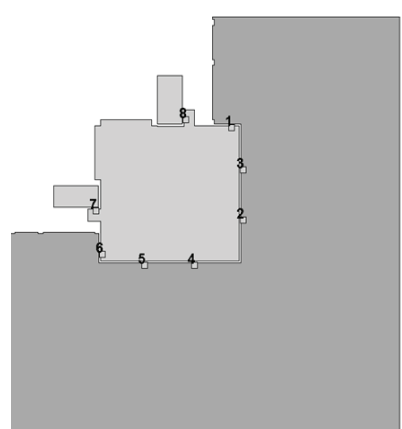

Fig. 4. Spatial Information Extraction
전달하는 것이며 Fig. 3 과 같은 형태로 도면을 변환한다. 또한 자동적으로 산출되는 기능 역시 포함한다. 이때, 주요 추출 정보는 벽체 재질, 시설물 재질, 배연설비, 문, 창문 등을 의미한다. MATL DB는 FDS 구동에 필요한 Data를 보완하기 위해 Excel을 통해 체계화 된 $\mathrm{DB}$ 를 구축한 것을 의미한다. Mesh Data는 Revit을 통해 화재모델을 제작할 때 Revit API에서 가져온 건축물의 외곽을 중심으로 연산하 여 화재모델의 Mesh를 설정하는 기능을 의미한다. Fig. 4 와 같이 FDS는 Mesh를 통해 분석이 이뤄지기 때문에 도면의 외곽을 자동으로 추출하여 이를 Mesh로 변환하게 된다.

다만, 수작업을 통해 화재모델을 입력할 때 자주 발생하는 문제 중 OBST와 GRID가 겹치며 가연물 형태나 내부의 벽과 같은 OBST가 인식되지 않는 경우가 있다. 이러한 문제점은 BIM에서 건축물의 외곽 정보를 연산할 때 발생할 수 있으므로 Fig. 5와 같이 OBST 사이에 눈에 보이지 않는 미세한 틈이 발생하는 경우에는 이를 자동적으로 인식하여 틈 사이를 채우게 된다.

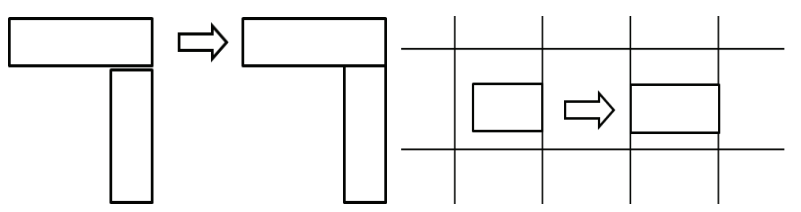

Fig. 5. FDS OBST Automatic Calibration Technique Algorithm

Analysis Options은 Mesh Data를 포함해 연기거동·온도· 연기농도·산소농도·가시거리 등 시각화가 필요시 되는 부분이 자동 설정되며, 필요시 사용자가 직접 원하는 정보를 얻을 수 있다. 이를 통해 FDSBIM은 Revit에서 화재공간을 제작하고 이를 $\mathrm{FDS}$ 파일로 변환시키게 된다.

변환 후 생성된 FDS 파일은 Smokeview.exe 프로세스와 FDS.exe로 생성되고 모듈의 구동은 FDS 6.5.3 버전으로 이뤄진다. 모든 구동이 완료된 이후에는 사용자가 구동된 결과값에 대한 기본적인 내용을 재확인 할 수 있으며, FDS파 일로 저장되고 화재시뮬레이션의 구동시간 동안 자동적으 로 스크립트가 실행된다. 
Table 2. Default Format of Database

\begin{tabular}{|c|c|c|c|c|c|}
\hline \multicolumn{2}{|r|}{ Tag } & Tag Name & Format & Maximum Time & Item Example \\
\hline \multicolumn{6}{|c|}{$<? \mathrm{xml}$ version="1.0" encoding="utf-8" ?> } \\
\hline \multicolumn{6}{|c|}{$<$ fdsMaterial $>$} \\
\hline \multicolumn{6}{|c|}{$<$ doc $>$} \\
\hline \multicolumn{2}{|c|}{$<$ doc_type $/>$} & Type & char & 1 & \\
\hline \multicolumn{2}{|c|}{$<$ att_date/> } & Date & char & 8 & \\
\hline \multicolumn{6}{|c|}{$</$ doc $>$} \\
\hline \multirow{6}{*}{$\begin{array}{c}\text { Repeating } \\
\text { Section }\end{array}$} & $<$ material $>$ & Material & & & \\
\hline & $<$ name $>$ & Material name & char & 255 & "FB_trashcan" \\
\hline & $<$ fireGrowthCoefficient $>$ & Fire-growth-rate & float & & 0.0003 \\
\hline & $<\operatorname{maxHrr}>$ & Max Hrr & float & & 100.0 \\
\hline & $<$ fireTime $>$ & Fire-time & float & & 480.0 \\
\hline & $</$ material $>$ & & & & \\
\hline
\end{tabular}

추가적으로 FDSBIM의 데이터베이스 구축을 위하여 Table 2와 같이 서로 다른 Revit의 건축물 데이터베이스와 FDS 데이터베이스를 하나로 통합하는 과정을 진행했으며, 화원으로 지정하는 경우에 선택할 수 있도록 열방출률 및 화재성장률 역시 적용했다.

Fig. 6은 FDSBIM의 시스템 구조와 데이터 및 신호가 작동하는 흐름을 나타내는 것으로 해당 프로그램은 플러그 인 모듈로서 저작도구인 Revit과 분석도구인 FDS와의 통신 방법을 연동시키게 되고, Fig. 7과 같은 GUI를 생성시키며 실행된다.

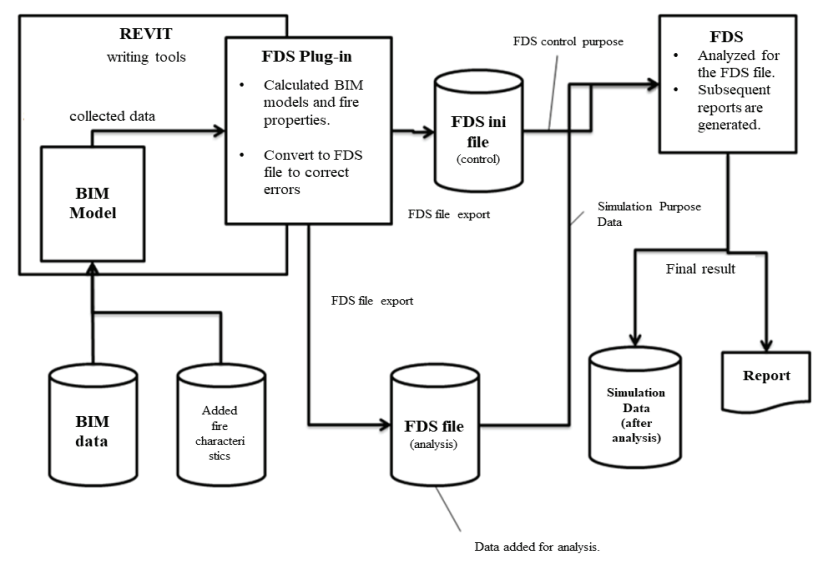

Fig. 6. System Structure and Signal Flow Diagram

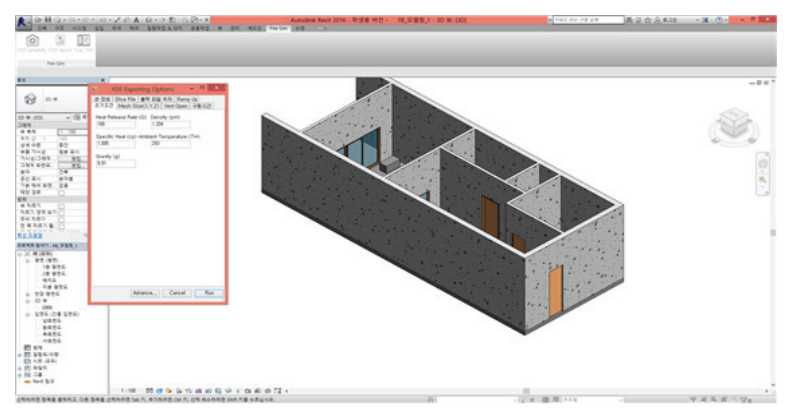

Fig. 7. Execution of FDSBIM

\section{Case Study}

\section{1 개요}

본 장에서는 FDSBIM의 시스템 테스트를 위해 Case Study 를 실시하였다. Revit 모델링을 FDSBIM으로 구동시키고 이에 대한 결과값을 $\mathrm{FDS}$ 와 비교하고자 한다.

Revit기반의 모델링 방법과 FDS 모델링 방법의 비교를 위한 목적으로 실내의 온도를 측정하였다.

소방시설 등의 성능위주설계방법 및 기준 별표1의3에서 는 인명안전기준 중 호흡한계선을 바닥에서부터 $1.8 \mathrm{~m}$ 의 높이의 온도가 $60{ }^{\circ} \mathrm{C}$ 이하일 때로 규정하고 있다. 따라서, 국내 기준을 근거로 바닥에서부터 $1.8 \mathrm{~m}$ 지점의 온도를 색깔로 나타내주는 SLCF를 분포해 시각화했으며 임의의 지점을 지정한 뒤 해당 구역의 온도를 측정하고 이를 비교하 였다. 먼저 FDSBIM의 데이터를 입력하는 방식은 Fig. 8과 같다. Revit을 통해 그려둔 도면을 불러온 뒤 초기 설정 값을 입력한다.

초기설정은 화원의 열방출률, 밀도, 실내온도, 중력으로


Fig. 8. FDSBIM Input Options 




Fig. 9. Floor Plan

Table 3. Analytical Condition

\begin{tabular}{c|c}
\hline Quantity & Model \\
\hline Time [sec] & 300 \\
\hline $\begin{array}{c}\text { Temperature Measurement } \\
\text { Position }\end{array}$ & $\begin{array}{c}\text { Installation at intervals of } \\
0.2 \mathrm{~m} \text { from the bottom of } \\
\text { the entrance to the ceiling }\end{array}$ \\
\hline Fuel & Methane \\
\hline Default Temperature $\left[{ }^{\circ} \mathrm{C}\right]$ & 20 \\
\hline $\begin{array}{c}\text { Heat Release Rate } \\
\text { Per Unit Area }\left[\mathrm{kW} / \mathrm{m}^{2}\right]\end{array}$ & 1,500 \\
\hline Vent Size $(\mathrm{W} \times \mathrm{D})[\mathrm{m}]$ & $3.0 \times 2.0$ \\
\hline $\begin{array}{c}\text { Mesh Size } \\
(\mathrm{W} \times \mathrm{D} \times \mathrm{H})[\mathrm{m}]\end{array}$ & $40.0 \times 15.0 \times 4.0$ \\
\hline $\begin{array}{c}\text { Cell Size } \\
(\mathrm{W} \times \mathrm{D} \times \mathrm{H})[\mathrm{m}]\end{array}$ & $0.2 \times 0.2 \times 0.2$ \\
\hline Number of Cells $[\mathrm{EA}]$ & $200 \times 75 \times 20=300,000$ \\
\hline
\end{tabular}

구성된다. 이후 Mesh의 Cell 크기를 정한다. 사용자가 원하는 경우에는 Custom을 통해 직접 크기를 설정할 수 있으며 아래 체크를 통해 오류가 발생하는지를 점검할 수 있다.

이후 구동시간과 시간대별 캡처기능을 선택한다. 이 때 $\mathrm{SLCF}$ 의 위치와 축을 정한 뒤 출력될 파일의 위치를 지정한다.

마지막으로 화원의 열방출률을 고려하여 Ramp 설정여부 를 결정한 뒤 Run 버튼을 누르면 FDS가 실행된다. 모델의 입면도는 Fig. 9와 같다.

구동에 필요한 조건은 Table 3 과 같다. 계산된 총 셀의 개수는 300,000 개이며 구동시간은 300 초, 초기온도는 20 ${ }^{\circ} \mathrm{C}$ 로 설정했다.

또한, Fig. 9에 표시한 것과 같이 임의의 3개 지점을 설정해 바닥에서부터 천장까지 $0.2 \mathrm{~m}$ 간격으로 온도를 측정했으며, 화재성장률은 고려하지 않고 동일한 열방출률이 발생하도 록 화원을 설정하였다.

\section{2 구동결과}

구동결과는 Table 4 와 같다. 스크립트는 $20 \mathrm{FPS}$ 단위로 측정했으며 이를 60 초 간격으로 표시하였다. SLCF 분포
Table 4. Result of SLCF

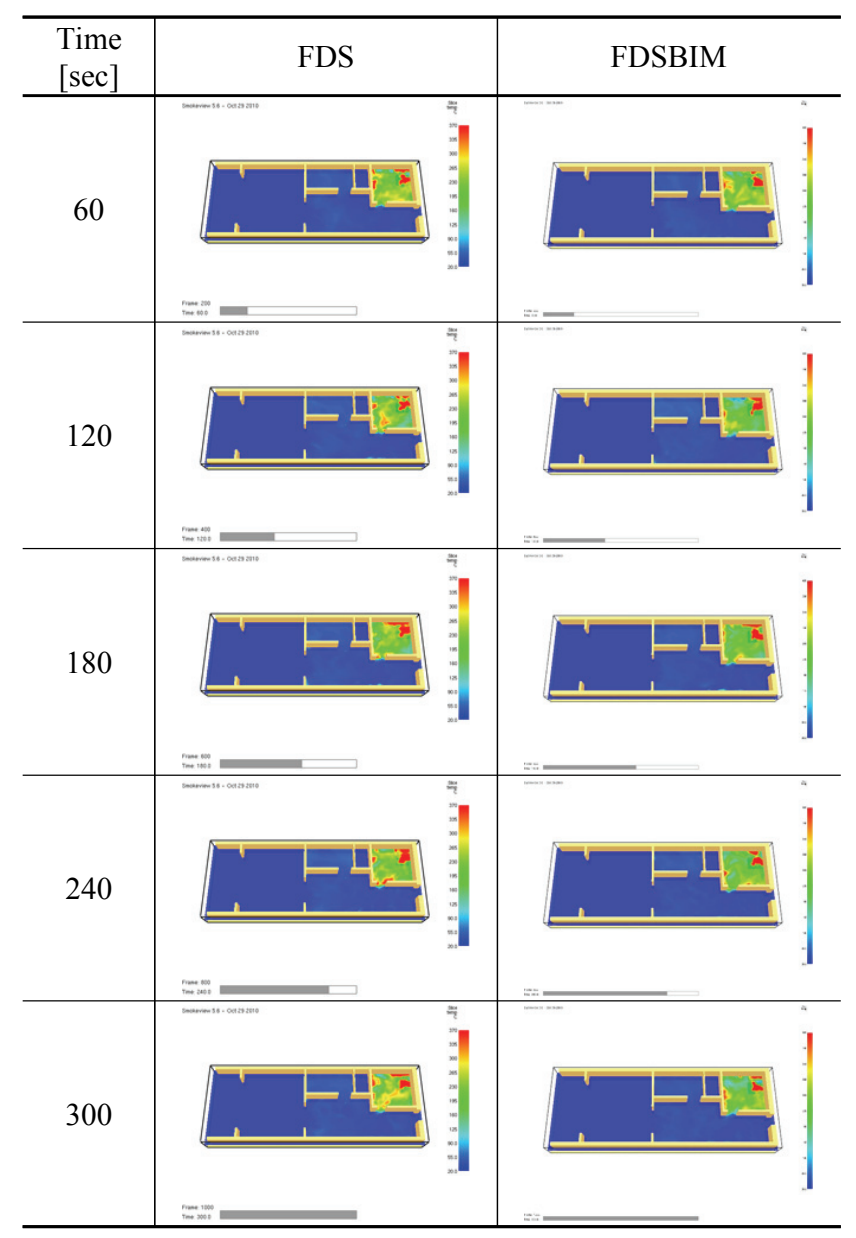

결과를 살펴보게 되면 60 초 간격으로 측정된 온도의 결과가 시각적으로는 뚜렷한 차이가 관찰되지 않았다.

다만 120 초가 경과하는 시점부터 FDS의 온도가 좀 더 높은 경향을 보이는 것으로 판단되며, $1.8 \mathrm{~m}$ 지점에서의 온도가 $60{ }^{\circ} \mathrm{C}$ 이상인가에 대한 판단이 어려움으로 이를 수치적으로 확인하고자 임의로 지정한 T-1, T-2, T-3 지점의 $1.8 \mathrm{~m}$ 온도 측정 결과를 비교하였다.

$\mathrm{T}-1$ 지점의 $1.8 \mathrm{~m}$ 온도 측정 결과는 Fig. 10 과 같다. FDS는 약 165 초가 경과한 시점에서 약 $50.86{ }^{\circ} \mathrm{C}$ 가 측정되었으며 $\mathrm{FDSBIM}$ 는 약 177 초가 경과한 시점에서 약 $51.17{ }^{\circ} \mathrm{C}$ 가 측정되었다. 양쪽의 최대 온도 차이는 약 $0.3{ }^{\circ} \mathrm{C}$ 이며 최대 온도까지 도달하는데 약 12 초의 차이가 발생했으며 $60{ }^{\circ} \mathrm{C}$ 는 도달하지 않은 것으로 측정되었다. 다만, 270 초가 경과하는 시점부터 FDS의 온도가 FDSBIM에 비해 약 20도 가량 높게 나타나는 형태를 보였다.

$\mathrm{T}-2$ 지점의 $1.8 \mathrm{~m}$ 온도 측정 결과는 Fig. 11과 같다. FDS는 약 133 초가 경과한 시점에서 약 $43.04{ }^{\circ} \mathrm{C}$ 가 측정되었으며 $\mathrm{FDSBIM}$ 는 약 153 초가 경과한 시점에서 약 $45.45{ }^{\circ} \mathrm{C}$ 가 측정되었다. 양쪽의 최대 온도 차이는 약 $2.4{ }^{\circ} \mathrm{C}$ 이며 최대 온도까지 도달하는데 약 20 초의 차이가 발생했으며, $60{ }^{\circ} \mathrm{C}$ 는 


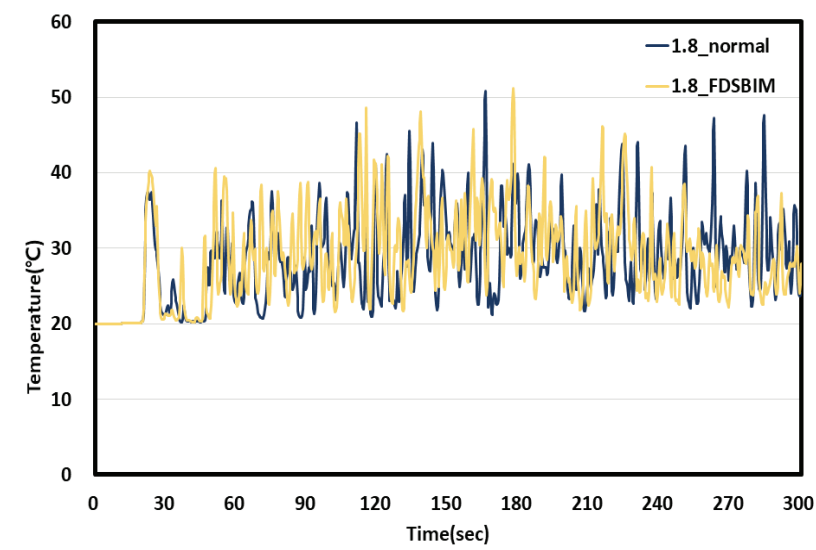

Fig. 10. Temperature of $1.8 \mathrm{~m}$ at $\mathrm{T}-1$ Point

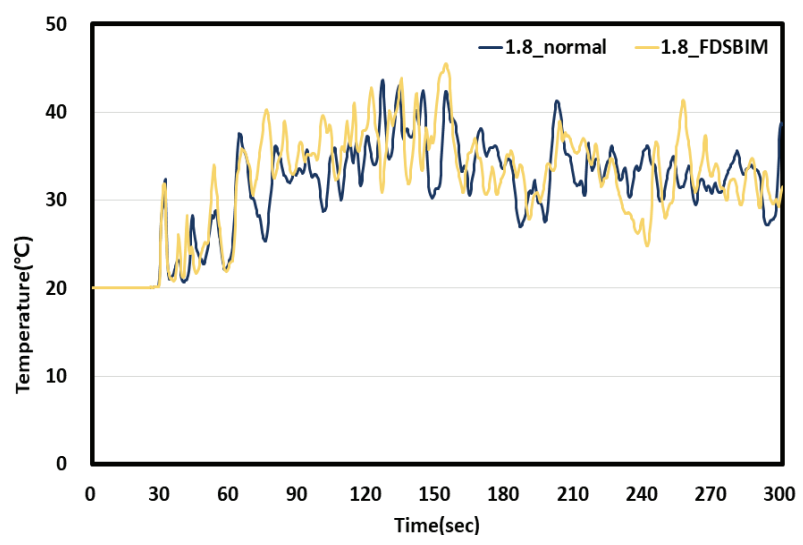

Fig. 11. Temperature of $1.8 \mathrm{~m}$ at $\mathrm{T}-2$ Point

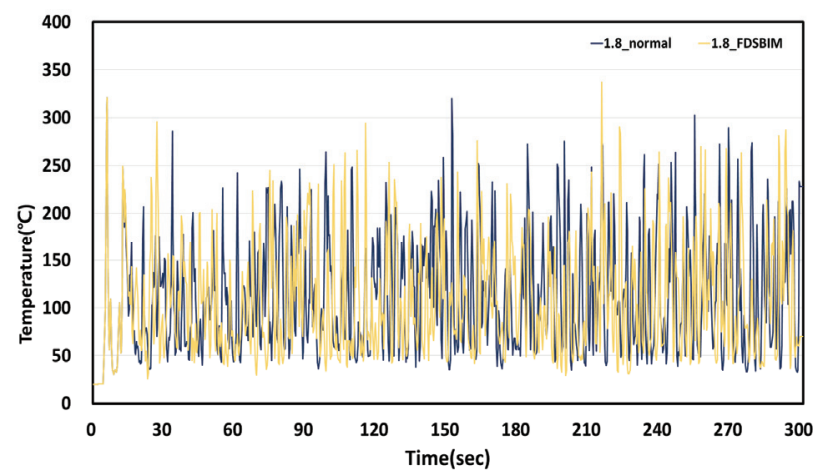

Fig. 12. Temperature of $1.8 \mathrm{~m}$ at $\mathrm{T}-3$ Point

도달하지 않은 것으로 측정되었다.

T-3 지점의 $1.8 \mathrm{~m}$ 온도 측정 결과는 Fig. 12 와 같다. 약 5 초가 경과한 시점에서 두 프로그램 모두 동일하게 약 65 ${ }^{\circ} \mathrm{C}$ 의 온도가 측정되었으며, $\mathrm{FDS}$ 는 약 152 초가 경과한 시점 에서 약 $320.04{ }^{\circ} \mathrm{C}$ 가 측정되었으며 FDSBIM는 약 216초가 경과한 시점에서 약 $337.05{ }^{\circ} \mathrm{C}$ 가 측정되었다. 양쪽의 최대 온도 차이는 약 $17{ }^{\circ} \mathrm{C}$ 이며 최대 온도까지 도달하는데 약 64초의 차이가 발생했다.

다만, T-3 지점의 온도 변화를 관찰해보면 약 20 초가
경과하는 시점까지는 온도가 거의 유사한 정황을 보이다가 시간이 지남에 따라 점차 차이를 보인다. 이는, 화재모델을 구축할 때 사용자가 직접 좌표를 입력하는 과정에서 컴퓨터 와 동일하게 좌표를 입력할 수 없는 소수점 이하의 좌표로 인해 연산에 차이가 발생하는 것으로 판단된다.

\section{5. 결 론}

본 연구에서는 BIM과 화재시뮬레이션의 연동방안과 Case Study를 통해 화재실의 온도를 비교하는 방식으로 프로그램의 테스트를 진행하였으며 다음과 같은 결론을 도출했다.

(1) 국내에서 사용빈도가 높은 Revit과 FDS의 연동에 필요한 기능조사를 통해 라이브러리를 하나로 통합하 는 과정을 수행했으며, 이를 4가지 단계로 구분하여 Revit API, MATL DB, Mesh Data, Analysis Options로 구체화시켰다.

(2) Case Study를 통해 온도비교를 실시하였다. 온도비교 결과 $\mathrm{T}-1$ 의 경우 약 $0.3{ }^{\circ} \mathrm{C}, \mathrm{T}-2$ 의 경우 약 $2.4{ }^{\circ} \mathrm{C}$, $\mathrm{T}-3$ 의 경우 약 $17{ }^{\circ} \mathrm{C}$ 의 차이를 보였으며, 최대온도까지 도달하는데 소요된 시간의 차이는 각각 약 12 초, 약 20 초 약 64 초의 차이를 보였다. 이는 최대한 유사하게 모델을 구축했음에도 불구하고 컴퓨터와 동일하게 좌 표를 입력할 수 없기 때문에 발생하는 차이로 사료된다.

다만, 1층 건축물을 대상으로 진행한 Case Study이기 때문 에 연산량이 많아질 때 어떤 차이가 발생할지에 대한 검토가 필요하다. 특히, 연산량이 많아지는 것으로 인해 결과에 큰 차이가 발생한다면 프로그램의 신뢰성이 의심될 수 밖에 없으므로 향후의 연구에서는 복합적인 건축물을 대상으로 다양한 화원을 적용해 Case Study를 진행할 필요가 있으며, 이를 실제 건축물 화재안전설계에 적용할 수 있는지에 대한 현장적용성 검토도 진행하고자 한다.

\section{감사의 글}

본 연구는 국토교통부 도시건축연구사업의 연구비지원 (20AUDP-B100356-06)에 의해 수행되었습니다.

\section{References}

Cho, H.J., Jang, J.S., and Kim, Y.S. (2016). Development of system module based on BIM technical contents data. Journal of the Korea Academia-Industrial cooperation Society, Vol. 17, No. 9, pp. 680-687.

Choi, C.H. (2009). A strategy for the introduction and 
development of BIM technology in the construction industry. Journal of the Korean Professional Engineers Association, Vol. 42, No. 5, pp. 23-28.

Kim, D.E. (2015). A study on the combustion characteristics of combustible materials and fire propagation for the analysis of fire behavior in domestic apartment house. Ph.D. dissertation, Hoseo University, pp. 113-119.

Lee, B.H. (2018). A study on the fire load and combustible characteristics for fire safety design related to BIM of building structures. Master's thesis, Hoseo University, pp. 46-70.

Lee, B.H., Jin, S.H., Kim, D.E., and Kwon, Y.J. (2020). An experimental study on the combustion characteristics of major combustible materials in office buildings. J. Korean Soc. Hazard Mitig., Vol. 20, No. 1, pp. 273-280.

Lee, B.H., Jin, S.H., Park, S.H., and Kwon, Y.J. (2019). A study on the review of repair methods and repair materials for the prevention of fire spread of building exterior materials. Fire Science and Engineering, Vol. 33, No. 3, pp. 105-111.

Lee, Y.G. (2010). A study on a BIM application in the early stage of building design process based on social information visualization. Journal of the Architectural Institute of Korea Planning \& Design, Vol. 26, No. 9, pp. 97-104.

Lee, Y.G. (2012). A basic study on the development of the technology of simulating the user's behavior in the real time manner within the BIM-based design process. Journal of the Architectural Institute of Korea Planning \& Design, Vol. 28, No. 12, pp. 157-164.

Lee, Y.G. (2015). A basic study on the development of a bim-based realtime performance evaluation technology for the user life safety in the buildings. Journal of Korea Multimedia Society, Vol. 18, No. 9, pp. 1058-1067.

Shin, J.H., Choi, J.S., Kim, I.H., and Yoon, D.Y. (2016). A study on development of integrated management system for BIM property information. Korean Journal of Computational Design and Engineering, Vol. 21, No. 2, pp. 130-142.

\begin{tabular}{l|l} 
Received & May 4, 2020 \\
Revised & May 7, 2020 \\
Accepted & May 12, 2020
\end{tabular} 